\title{
What is it like to be a god? A philosophical clarification of instances of divine suffering in the Psalter
}

\author{
Author: \\ Jaco W. Gericke \\ Affiliation: \\ ${ }^{1}$ School of Basic Sciences, \\ Faculty of Humanities, North- \\ West University, South Africa \\ Correspondence to: \\ Jaco Gericke \\ Email: \\ 21609268@nwu.ac.za \\ Postal address: \\ Internal Box 125, Vaal \\ Triangle Campus, North-West \\ University, PO Box 1174, \\ Vanderbijlpark 1900, \\ South Africa \\ Dates: \\ Received: 22 Nov. 2011 \\ Accepted: 09 Mar. 2012 \\ Published: 28 May 2012 \\ How to cite this article: \\ Gericke, J.W., 2012, 'What \\ is it like to be a god? A \\ philosophical clarification of \\ instances of divine suffering \\ in the Psalter', Verbum et \\ Ecclesia 33(1), Art. \#700, \\ 6 pages. $\mathrm{http}: / / \mathrm{dx}$.doi. \\ org/10.4102/ve.v33i1.700
}

C) 2012. The Authors. Licensee: AOSIS OpenJournals. This work is licensed under the Creative Commons Attribution License.
There are times when one would like to hang the whole human race, and finish the farce. (Mark Twain)

In philosophy of religion, there is a long history of belief that divine reality is immutable, although this has changed recently. In this article, the author takes a closer look at what some texts in the Psalms assumed about what it feels like for a god to suffer mentally. By paying attention to what is presupposed in language about negative divine emotions, the nature of mental anguish in the life of a deity is elucidated from examples in the text in which Yhwh is said to have states of mind involving anger, hate, compassion, jealousy and grief.

\section{Introduction}

A few decades ago, the philosopher of mind Thomas Nagel wrote a paper called What is it like to be a bat? (Nagel 1974:435-450). Nagel allegedly chose bats instead of wasps or flounders because, if one travels too far down the phylogenetic tree, people gradually shed their faith that one can find experience there at all. Bats, although more closely related to us than those other species, nevertheless present a range of activity and a sensory apparatus so different from ours that the problem is exceptionally vivid. Nagel suggests that anyone who has spent some time in an enclosed space with an excited bat knows what it is to encounter a fundamentally alien form of life.

Nagel noted that bats perceive the external world primarily by sonar, or echolocation, detecting the reflections, from objects within range, of their own rapid, subtly modulated, high frequency shrieks. Their brains are designed to correlate the outgoing impulses with the subsequent echoes, and the information thus acquired enables bats to make precise discriminations of distance, size, shape, motion and texture comparable to those we make by vision. Nagel also challenged his readers to imagine that one has webbing on one's arms, which enables one to fly around at dusk or that - almost blind - one perceives the surrounding world by a system of reflected high frequency sound signals. For Nagel this imagined example does not go far enough: It tells me only what it would be like for me to behave like a bat. As Nagel shows, that is not the question. He wants to know what it is like for a bat to be a bat.

In this paper I would like to ask a similar if not stranger question: What it is like to be a god? I would agree with Nagel's argument so that, in one sense, I know my question is impossible to answer. Instead of trying to put forward any account of divine subjectivity with a transcendental pretence, I rather wish to look at what some texts in the Book of Psalms assumed it was like to be a god. More to the point, my focus will be on images of the divine's experience of suffering - a traditionally atypical subject matter in philosophy of religion sometimes neglected in discussions of suffering in biblical literature (see Fretheim 1982). Whilst the concept of suffering is stereotypically associated with physical pain, the interest here lies with what the texts presupposed, if you will, about what appears to be the mental pain that was assumed to be part and parcel of being a god, i.e. some of the more unpleasant feelings or negative emotions the god Yhwh was assumed to experience.

\section{The history of a dogma}

Gods who suffer emotionally are familiar characters in ancient Near Eastern mythology (Tortchinov 1998:150-151). One can find many examples of male and female divine beings who experience all sorts of mental pain in various ways and for various reasons. Particularly familiar are instances of gods depicted as frustrated, fearful or in mourning. The idea of the suffering deity became problematic in the writings of some Greek philosophers like Plato and Aristotle. These thinkers insinuated that a god cannot suffer as humans do since it is perfect, omnipotent, omniscient and immortal (the so-called 'perfect-being theology') and because mental vulnerability was considered to be shameful. 
The Hellenistic Jewish philosopher Philo prepared the way for the Greek Fathers by adding apatheia as a property of post-biblical Christian understandings of the god of Israel. After that, belief in divine impassibility was often taken for granted, that is, the notion that anything worthy of being classified as a god by way of its nature does not experience change or suffers from the actions of another being (see Weinandy 2000). This doctrine followed logically from the concept of divine aseity, the belief that a god is something ontologically independent of every other being. These ideas were virtually axiomatic in much of Christian philosophical theology until the 19th century (with exceptions here and there) (see Gavrilyuk 2006).

The dogma of divine immutability would be modified or abandoned altogether by prominent Christian theologians in the 20th century (e.g., Brunner, Barth, Bonhoeffer, Moltmann, and others). More recently, the Continental philosopher of religion John Caputo summarised the problem related to juxtaposing God's metaphysical and personal attributes as follows (see Trakakis 2007):

That very finite Hellenistic creature called 'God' is a being cut to fit the narrow needs of Greek ontology, of Parmenides and Plato, who were scandalized by time and motion and change, and of Aristotle, who did the best he could to make the name of matter and motion respectable among the Greeks. But from a biblical point of view, this highly Hellenic theos was an imperfect - may I say a pathetic, or better an apathetic? - way to think of God. It had nothing to do with Yahweh who was easily moved to anger and jealousy, who was a God of tears and compassion, who suffered with his suffering people, who was moved by their sighs and lamentations, who was angered by their meanness of mind and had a well-known and much respected temper, who had, in short, a short fuse. (p. 38)

Belief in divine mutability (and therewith vulnerability to suffering) is nowadays typically associated with so-called Open-theism (Pinnock et al. 1994). This perspective has become fashionable also in Old Testament theology, perhaps the best example of which is the work of Fretheim (1982). In The Suffering of God, Fretheim sets out to show how and where the Old Testament contradicts elements of'perfect being' theology by way of biblical examples of limitations in divine knowledge and power and instances of divine suffering as inferred by references to Yhwh experiencing painful emotions. Another familiar sustained attention to Yhwh's passionate nature is the theology of Walter Brueggemann (1997:passim). Virtually all non-fundamentalist literary critics also tend to take it for granted that the god of Israel as depicted in biblical narratives was not assumed to be personally unacquainted with severe emotional turmoil (e.g. Miles 1995). Even in such cases, however, biblical theology remains influenced by anachronistic notions in philosophy of religion. Religious language about divine emotions, though held to be in need of recognition, is still often made to seem less obviously anthropomorphic by claiming that all such god-talk was actually 'metaphorical' all along.

\section{How a god suffers emotionally}

What this paper will contribute to the on-going discussion is a comparative philosophical clarification of a few types of mental suffering a god (in this case Yhwh) was assumed to undergo, based on inferences from textual examples of negative divine emotions in the Psalter (cf. De Sousa 2010:n.p.). Since the aim is description and elucidation rather than justification or critique, I make no normative theological claims about what is the case absolutely in the world behind or in front of the text. My focus is on the deity and its affections as literary constructs. My argument is that, if we can agree that mental pain accompanies emotions like anger, rage, hate, frustration, indignation, resentment, disappointment, rejection, pity, grief and sadness, we must grant that a character who was assumed to experience such emotions was also believed to be suffering in some sense.

To be open to this argument, we must set aside our modern preconceptions about what a god should or should not be like and attend to the text as it stands. Being pre-philosophical, the Psalms show no embarrassment at attributing what we nowadays recognise to be all-too-human characteristics to the divine. Taken seriously for what it is, conceptions of godhood in the Psalter are often 'unsophisticated' relative to the standards for maximal greatness in contemporary Christian philosophies of religion. This is the case, despite representations of the deity being obviously less anthropomorphic than what we find in many neighbouring ancient Near Eastern myths. So to avoid reading our own anachronistic meta-theistic assumptions into the text, we need to bracket the classical theistic view that references to divine emotion are all merely analogical or symbolical language (anthropopathism), the Kantian idea that a god is altogether transcendent and the Heideggerian objection to onto-theology.

\section{Divine anger}

Many people would not intuitively associate the emotion of divine anger with divine suffering since it suggests the expression of power. Yet ancient Greek philosophers who reflected on the matter suggested a definite link between anger and emotional pain (Hughes 2001:67). Aristotle, for example, thought that anger arose from the pain of suffering a perceived injustice. Other early philosophers regarded anger as a painful kind of madness. During the medieval period, the Jewish philosopher Maimonides considered an agent being given to uncontrollable anger as suffering from a kind of mental illness. The modern understanding of anger did not greatly advance over that of ancient and medieval views (Hughes 2001:68). In subsequent writings on the subject, there is a consensus that anger arises from mental suffering related to the psychological interpretation of having been offended, wronged or denied. Anger is held to be driven by a desire to blunt, express or relieve emotional pain due to the uncomfortable experience of a perceived provocation (Ben Zeev 2001:39). 
Viewed from this perspective, we may conclude that texts from the Psalms referring to divine anger presuppose the reality of some sort of discomfort and therefore of a certain amount of mental suffering for the deity. In fact, according to some texts in the Psalter, Yhwh experienced acute states of this negative emotion and was often in need of venting his pent-up frustration. Many examples of this are present in the Psalms, of which for practical purposes, I shall note only two.

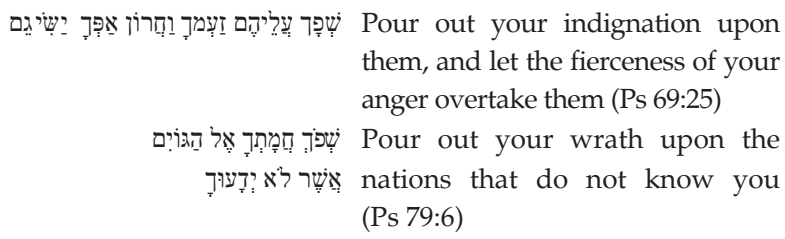

The imagery employed here contains the metaphor of a container of some sort that is overheating. The metaphor of Yhwh as a repository of coals and fire and who has to divulge himself of its contents for the relief from the unbearable state of anger is poignant. Indeed, to the modern lay-reader, this particular representation of the divine will be more reminiscent of the devil of popular mythology, as is clearly the case in Psalm 18:

$$
\begin{aligned}
& \text { Smoke rose up in his nose }
\end{aligned}
$$

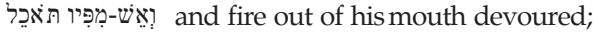

$$
\begin{aligned}
& \text { coals flamed forth from him } \\
& \text { (Ps 18:9) }
\end{aligned}
$$

Though the imagery of fire inside a god is not prima facie associated with mental pain, the psycho-somatic unity of many Old Testament notions of selfhood makes the distinction anachronistic. The emotion of anger, and the need for expression that accompanies it, also imply some psychological (and therefore physiological) sensation of severe inner turmoil. This is not just colourful theological language. In many Old Testament texts, the god of Israel was assumed to have a physical body and was therefore not imagined to be incorporeal like the God of the Philosophers (see Sommer 2009). To be sure, in the texts from the Psalms above, we are dealing with poetry which is often not intended literally. Yet we cannot reduce these images to an orthodox philosophical minimum for they make no sense without the vivid materialism.

Of interest is the fact that not only the god's natural enemies are seen as a cause for divine suffering. Sometimes, divine anger follows from the actions of Yhwh's own people:

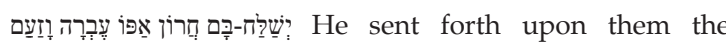

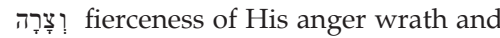

In the Psalter, these types of references to divine anger are most frequently found in allusions to the Exodus and wilderness traditions. And whilst, as noted above, most readers might wish to reinterpret or downplay references to divine anger qua divine suffering, these texts from the Psalter definitely presuppose that a god also experiences the typical mental suffering that go with this emotion. The obviousness of this becomes more readily apparent when we turn our attention to the next negative emotion on our list - hate.

\section{Divine hate}

Philosophers have offered many influential definitions of hatred. As Royzman et al. (2005) notes, Descartes viewed hate as the awareness that something is bad, combined with an urge to withdraw from it, whilst Spinoza defined hate as a type of pain that is due to an external cause. It is also well known that, in classical psychoanalysis, Freud defined hate as an ego state that wants to destroy the source of its unhappiness and suffering. More recently, the Penguin Dictionary of Psychology defined hate as a deep, enduring, intense emotion expressing animosity, anger, and hostility towards a person, group, or object (see Reber 2001).

For present purposes, suffice it to note that, according to some Psalms, this uncomfortable mental state is also assumed to be a painful reality in the divine mind. In the Psalms, we find that this form of suffering was catalysed by humans who opposed the god's will through transgressing the divine law. Thus there seems to be an element of intense displeasure for a god as a result of moral evil.

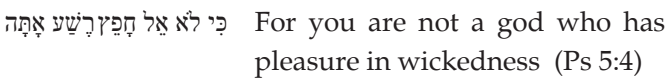

Some texts in the Psalter also suggest that being a god like Yhwh meant that there are people whose presence or actions are painful to endure.

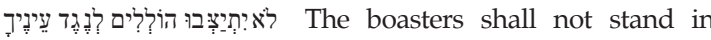

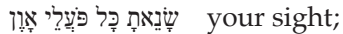

$$
\begin{aligned}
& \text { You hate all workers of iniquity } \\
& \text { (Ps 5:5) }
\end{aligned}
$$

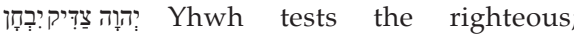

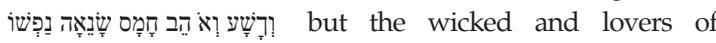

$$
\begin{aligned}
& \text { violence he hates (Ps 11:5) }
\end{aligned}
$$

That the emotion of hate was assumed to hurt the god emotionally in some way can be seen in texts presupposing a diminishment of vital powers and possessions for the deity as a result thereof. This is evident in the references to the loss of 'strength' and 'glory' in the following two verses.

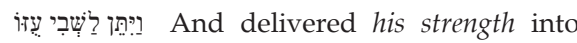

$$
\begin{aligned}
& \text { captivity, and his glory into the } \\
& \text { adversary's hand. } \\
& \text { He gave his people over also unto } \\
& \text { the sword; and was wroth with }
\end{aligned}
$$

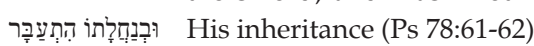

To be sure, the reference is to the people, but here they are represented as an extension of the god's own power. In the same line of thought - that of divine energy dissipating another text seems to presuppose that the suffering caused by the emotion of hate in the divine could be signified quantitatively as involving temporal duration.

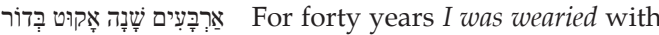

$$
\begin{aligned}
& \text { that generation (Ps 95:10) }
\end{aligned}
$$

According to this verse at least and contrary to notions in stereotypical classical philosophical theology (that a god is a-temporal), time takes its toll even on a god. The bottom 
line here therefore is that, at least for some psalmists, Yhwh experienced some emotional pain as a result of hating something he actually cared a lot about. In this sense then, a certain amount of hateful suffering was believed to be part and parcel of what it's like to be a god. But there is more: also the opposite emotion in a god involved suffering - pity.

\section{Divine compassion}

A third manner in which a god like Yhwh was assumed to suffer was through the experience of pity or compassion. Pity originally meant feeling for others, particularly feelings of sadness (Konstan 2001:180). The English noun compassion is related to the concept of pity in its traditional sense and means to suffer together with. More vigorous an emotion than empathy alone, the concept comes from the Latin denoting emotional capacities for sympathy in relation to the suffering of others. According to Konstan (2001:181), in Ancient Greece, Aristotle argued that, before an agent can feel pity for another, the agent must have an idea of what it is like to experience suffering of a similar type. On this view, genuine pity is a mild to severe kind of pain experienced in the case of being concerned with the apparent harm of someone not deserving to encounter it. An agent experiencing pity will feel intense sorrow for the sufferer.

That the notion of divine pity in a number of texts from the Psalter also implies the idea of divine suffering is more obvious if we remember Nietzsche's insight that pity is the multiplication of suffering, in that it allows the one who pities to suffer along with those for whom is felt pity (Nietzsche 1954:608-609). In these Psalms, it is assumed that a god should feel the pain of pity and can be influenced to experience the emotion to such an extent that it will be motivated by pure sadness to act for the salvation of the servant.

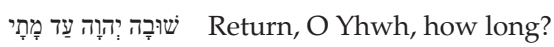

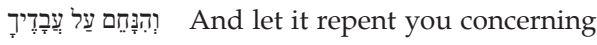

$$
\begin{aligned}
& \text { your servants } \\
& \text { (Ps 90:13) }
\end{aligned}
$$

As is readily apparent, this kind of compassion was also associated with the familiar albeit controversial Old Testament notion of divine repentance that is usually seen as a painful regret in the mind of Yhwh after having judged people with a bit of an overkill. The fact is that, according to an old credo found in various formulations and contexts in the Psalter, Yhwh was known for being a god who is full of 'co-suffering':

$$
\begin{aligned}
& \text { Compassionate and merciful is }
\end{aligned}
$$

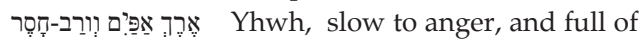

$$
\begin{aligned}
& \text { mercy } \\
& \text { (Ps 103:8; cf. 86:15; 111:4; 112:4; } \\
& \text { 145:8) }
\end{aligned}
$$

To experience these emotions involves the emotional pain of feeling sorry for the creature. However, because not even a god can be just and merciful at the same time, at least one text recognised that the divine suffers from the tender compassion found in a parent-child relationship,

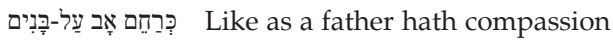

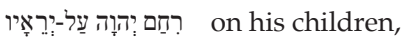

so is the compassion of Yhwh for those fearing him (Ps 103:13).

Divine pity or compassion also involved feeling sorry for entire cities or peoples, the judging of which was demanded by justice but which gave Yhwh no pleasure. After all, for the divine, it meant having to undergo a period of self-constraint before he could relent and relieve himself of a certain amount of inner pressure:

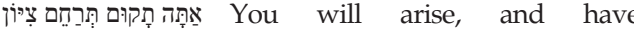

$$
\begin{aligned}
& \text { compassion upon Zion; } \\
& \text { Because of a time of mercy on her, } \\
& \text { for the time is come (Ps 102:13) }
\end{aligned}
$$

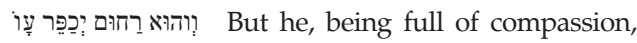

$$
\begin{aligned}
& \text { וְל אי בְּשִחית forgave iniquity, } \\
& \text { and did not destroy (Ps 78:38) }
\end{aligned}
$$

To the orthodox eye, these instances of pity may look painless, but psychological clarification of the experience of the emotion clearly shows that these texts presuppose some amount of mental suffering for the god whose heart was saddened by the mess humans often got themselves into. On this point, even the atheist philosopher Arthur Schopenhauer could feel pity and allegedly on the night before he died was reputed to have said:

If a god made the world, I would not want to be that god, for the misery in the world would break my heart.

In sum then, for some Psalmists, being a god was not assumed to involve living in a perpetual state of bliss. On the contrary, the divine condition also included the kind of emotional pain to be had from sympathy with the objects of one's affection.

\section{Divine jealousy and grief}

Divine jealousy is a familiar and, for many an apologist or biblical theologian, often an embarrassing notion in Old Testament god-talk. Yet as is the case with the painful emotions already mentioned, references to Yhwh's jealousy were not considered to be a mere metaphor. Hence the inordinate number of casualties in Yhwh's crimes of passion. Yet many biblical scholars seem to be more interested in explaining away or rationalising the emotion of divine jealousy than in paying attention to the emotional suffering it presupposes. Jealousy can be a very painful emotion exacerbated by a number of uncomfortable accompanying feelings, including fear of loss, anger about a perceived betrayal, shame and sadness and distrust.

According to one model, jealousy usually involves three parties, the subject, the rival and the beloved (cf. Tarico 2011:155-178). So from a religious-historical context, divine jealousy presupposes monolatrism rather than monotheism. Yhwh is jealous of other gods who were assumed to exist (one is not jealous of non-existent beings), and he wants his beloved (Israel) to worship him only. In such a worldview, every god inherits a nation (see Dt 32:8-9Q) and experiences 
jealousy when its people turn to other gods. In view of all this, a god's mental suffering seems to be presupposed in references to the divine jealousy some psalmists depicted Yhwh as having to deal with.

$$
\begin{aligned}
& \text { But they turned back and dealt }
\end{aligned}
$$

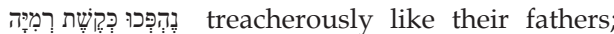

According to some Psalms, therefore, to be a god like Yhwh was assumed to involve suffering from jealousy as a result of apostasy, rejection and disappointment. This is different from the jealousy of the Greek gods where the sexual dimension was more prominent in the manifestation of the emotion. In ancient Israelite religion, sexual jealousy functioned more on a metaphorical level when Yhwh is the wronged partner. Whilst it may sound petty in the context of classical theism's perfect-being theology, in biblical god-talk this kind of suffering is associated with the values of honour and shame; in this case, it is the shame of rejection. Yhwh cannot forgive and 'get over it', and some texts seem to presuppose that he is in fact a 'slave' to this passion which burned not only others but also himself:

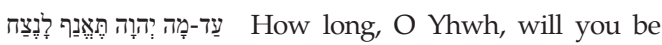

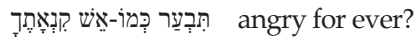

How long will your jealousy burn like fire? (Ps 79:5)

Burning presupposes suffering. Divine jealousy was assumed to be a god's own private hell and the result of a seemingly justified sense of entitlement and possessiveness. The nature of suffering in more monotheistic texts eventually turned the emotion into a global sense of shame. For example, not assumed to be omniscient or omnipresent in the philosophical-theological sense, Yhwh is depicted by one text as spending his time looking for interested parties:

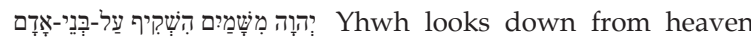

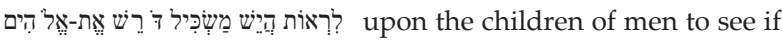
there were anyone understanding, that seek after God.

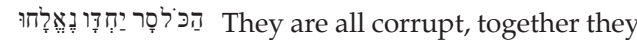

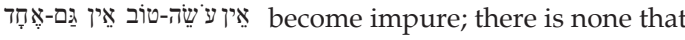
does good, not one (Ps 14:2-3)

To be a hidden god was by definition to feel as if nobody really understands you. Though instantiating the property of being mysterious is considered to be a good thing for the divine in many popular theologies, for Yhwh, in some texts in the Psalter, not being understood was also endlessly frustrating. So whereas for the atheist existentialist philosopher Sartre hell was other people, for a god like Yhwh hell could be all people. To be the only god and also ethically superior to humans were to be surrounded by moral incompetents.

Even when Yhwh did not lose someone through unfaithfulness, the end result of the deity's relationship with humans was believed to involve eternal separation. This was no cold and clinical mathematical operation of deduction. At least one psalm implies that to be a god is to be negatively impacted by the death of those one loves, and to suffer as a result:

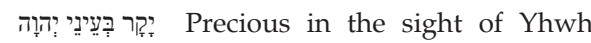

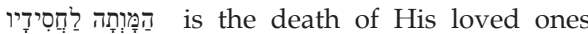
(Ps 116:15)

So in this text, it is assumed that, also for a god like Yhwh, the loss of something precious was assumed to be a source of intense emotional pain. If we remember that, according to research on stress in contemporary psychology, the process of bereavement after the death of a loved one is one of the most stressful events one can experience, it is clear that divine suffering was also presupposed at the death of favoured individuals. And since for many of the Psalmists, all individuals go to Sheol (and do not join Yhwh in heaven, as popular Christian views of the afterlife would have it), also for a god, the death of those close to one's heart was assumed to be something permanent (see Ps 6, Ps 30, Ps 88, contra Ps 139 , etc.). As such, recognition of human mortality meant a priori the belief that the divine could not avoid suffering.

\section{Conclusion}

In classical Christian philosophical theology and contemporary popular belief, to be divine means to remain psychologically sensitive but nevertheless essentially immune to the metaphysical, moral and natural evil in the world. This idea has led many to envy the divine condition. As Nietzsche (1968) quotes the ancient philosopher Theages who said:

Each one of us would like to be master over all men, if possible, and best of all, a god. (p. 18)

Looking at the negative emotions involved in being a god as we find them depicted in some texts in the Psalter, we can let go of our envy. The divine condition, like the human one, was assumed to involve suffering from negative emotions like anger, hate, pity, jealousy and grief on a scale beyond all decent contemplation. And if we forego the temptation to anachronistically reinterpret the Psalter's language about divine feelings as being mere metaphorical anthropopathism, we may conclude that, at least according to some of the Psalms, being a god was not easy.

\section{Acknowledgement Competing interests}

The author declares that he has no financial or personal relationship(s) which may have inappropriately influenced him in writing this paper.

\section{References}

Ben Zeev, A., 2000, The Subtlety of Emotions, MIT Press, Cambridge.

Brueggemann, W., 1997, Old Testament Theology: Testimony, Dispute, Advocacy, Fortress Press, Minneapolis. 
De Sousa, R., 2010, 'Emotion', in E.N. Zalta, The Stanford Encyclopaedia of Philosophy, viewed 27 July 2011, from http://plato.stanford.edu/archives/spr2010/entries/ emotion/

Fretheim, T.E., 1984, The Suffering of God, Fortress Press, Minneapolis.

Gavrilyuk, P.L., 2006, The Suffering of the Impassible God: The Dialectics of Patristic Thought, Oxford University Press, Oxford.

Hughes, P.M., 2001, 'Anger,' Encyclopaedia of Ethics, Vol I, 2nd edn., pp. 67-71, Routledge Press, New York.

Miles, J., 1995, God: A Biography, Alfred Knopf, New York.

Konstan, D., 2001, Pity Transformed, Duckworth, London.

Pinnock, C., Price, R., Sanders, J., Hasker, W. \& Basinger, D., 1994, The Openness of God, InterVarsity, Downers Grove.

Nagel, T., 1974, 'What Is it Like to Be a Bat?', Philosophical Review, 435-50. http:// dx.doi.org/10.2307/2183914

Nietzsche, F., 1954, The Antichrist, Penguin, London.
Nietzsche, F., 1968, The Will to Power: In Science, Nature, Society and Art, Random House, New York.

Reber, A.S., 2001, The Penguin Dictionary of Psychology, Penguin Books Ltd., London.

Royzman, E.B., Drake, C., Jackson, P., 2005, 'From Plato to Putnam: Four ways to think about hate,' in R.J. Sternberg, The Psychology of Hate, pp. 3-35, American Psychological Association (APA), Washington D.C.

Sommer, B.D., 2009, The Bodies of God and the World of Ancient Israel, Cambridge University Press, Cambridge.

Tarico, V., 2011, 'God's Emotions: Why the Biblical God Is Hopelessly Human,' in J.W. Loftus, The End of Christianity, pp. 155-178, Prometheus Press, New York.

Tortchinov, E., 1998 "Cybil, Attis and the Mysteries of the "Suffering Gods" - A Transpersonal Interpretation,' International Journal of Transpersonal Studies 17(2), 149-159.

Trakakis, N., 2007, 'Meta-Philosophy of Religion', Ars Disputandi 7, 1-47.

Weinandy, T.G., 2000, Does God Suffer? University of Notre Dame Press, Notre Dame. 